\title{
Antifouling potential of Thalassia hemprichii extract against growth of biofilm-forming bacteria
}

\author{
Fahruddin Fahruddin*, Eva Johannes, Zaraswati Dwyana \\ Department of Biology, Faculty of Mathematics and Natural Sciences, Hasanuddin University, Makassar, \\ Indonesia 90245
}

*Corresponding author, e-mail: fahruddin_science@unhas.ac.id

Received 17 Jul 2018

Accepted 28 Jan 2019

\begin{abstract}
Many types of seagrass are known to produce active compounds, including those with the ability to function as antimicrobials. This study focused on the potential of crude methanol extract from the seagrass Thalassia hemprichii as an antimicrofouling agent. Seagrass T. hemprichii was macerated and then extracted with methanol. To identify active components, biofilm bacterial inhibition assays were performed using the diffusion method. Isolates of biofilm-forming bacteria were characterized and placed into eight groups. Bacterial inhibition assays demonstrated that T. hemprichii extract was able to inhibit the growth of biofilm-forming bacteria, producing a 26 mm inhibition zone. The effects of T. hemprichii extract was similar to chloramphenicol, which formed a $28 \mathrm{~mm}$ inhibition zone. No inhibition zone was observed using methanol, the extraction solvent. The growth inhibitory properties of T. hemprichii extract were further examined for each bacterial isolate. Inhibition zones produced by T. hemprichii extract using several bacterial isolates were similar to chloramphenicol (27 mm): P1, $26 \mathrm{~mm}$; P3, $27 \mathrm{~mm}$; P4, $24 \mathrm{~mm}$; P7, $26 \mathrm{~mm}$; and P8, $26 \mathrm{~mm}$. In contrast, T. hemprichii extract was less effective at inhibiting the growth of other bacterial isolates: P2, $21 \mathrm{~mm}$; P5, $14 \mathrm{~mm}$; and P6, $9 \mathrm{~mm}$. Overall, our analysis demonstrates that T. hemprichii extract can inhibit the growth of biofilm-forming bacteria, proving its potential as an antimicrofouling agent.
\end{abstract}

KEYWORDS: antibiofouling, inhibition zone

\section{INTRODUCTION}

Biofouling is one of the most important problems currently facing the marine industry. Primary causes, in both marine and freshwater environments, are related to sunken ships and the presence of other materials underwater. There are two types of biofouling, microfouling and macrofouling ${ }^{1}$. Microfouling includes bacteria, fungi or algae that grow attached to floating objects inundated by seawater. Macrofouling is mostly caused by barnacles (Balanus) which are broadly distributed in coastal regions and estuaries. Barnacles are found on hard natural surfaces as well as artificial substrates, especially in intertidal zones ${ }^{2}$.

Currently, the prevention of biofouling uses tributyltin (TBT)-based antifouling paint, which has been proven to be very effective in dealing with fouling cause organisms. However, adverse environmental side effects, especially toxicity to nontarget organisms, has resulted in a ban on the use of TBT in many countries ${ }^{3}$. In addition, the International Maritime Organization has issued a resolution endorsing a restriction on the use of TBT- based paint on ships ${ }^{4}$. Other chemicals commonly used as antifouling additives in paint are arsenic, organo-mercury, DDT, and tin ${ }^{5}$. These chemicals have hazardous toxic effects, high persistence in the environment, and can harm many marine organisms ${ }^{6,7}$. Hence there is a need to develop a substitute for these antibiofouling chemicals, such as natural products, that are more environmentally friendly.

Seagrass is one of several sea plants known to have active compounds that may have utility as an antibiofouling agent ${ }^{8}$. Thus an investigation into the potential of bioactive compounds present in seagrass may allow for the production of new antibiofouling compounds. Seagrass is grown throughout the ocean in tropical regions, especially near Indonesia. In addition to the ready supply of seagrass as a source of antibiofouling material, there are several advantages of natural products as antifouling agents including being environmental-friendly, nonmutagenic and non-carcinogenic; easily obtained from natural sources; and increased effectiveness, as some natural product have higher activities than chemicals currently in use ${ }^{9}$. 
There are many seagrass species in the ocean surrounding Indonesia, including 12 species from 7 different genera. The species that have been characterized are as follows: Cymodocea rotundata, C. serrulata, Enhalus acoroides, Halodule uninervis, Halodule pinifolia, Halophila decipiens, Halophila minor, Halophila ovalis, Halophila spinulosa, Syringodium isoetifolium, Thalassia hemprichii, and Thalassodendron ciliatum ${ }^{10,11}$. The extent of seagrass in Indonesian coastal areas is estimated to reach $30000 \mathrm{~km}^{2}$ and this large natural resource is currently under-utilized ${ }^{12}$. Seagrass may contain natural products capable of retarding the growth of microorganisms that colonize the surface of submerged objects, forming a sheet called a biofilm ${ }^{14}$. Antifouling agents are utilized to prevent the growth of biofilm-forming bacteria on materials in seawater $^{13}$.

Seagrass has bioactive compounds and a great potential for providing the raw material for pharmaceutical, cosmetic, food, and other biotechnology industries ${ }^{14,15}$. Several seagrass species exhibit antibacterial activity including Thalassia hemprichii, Halodule pinnifolia, S. isoetifolium, C. serrulata, and C. rotundata ${ }^{16}$. Seagrass T. hemprichii is among the aquatic plants known to produce triterpenoids, flavonoids, and phenol hydroquinones that function as antibacterial agents ${ }^{17}$. In addition, the compounds produced by T. hemprichii exhibit antioxidant activity ${ }^{18}$. Hence this study examined the potential of bioactive compounds present in extracts from the seagrass $T$. hemprichii to inhibit the growth of biofilm-forming bacteria.

\section{MATERIALS AND METHODS}

\section{Sampling}

Samples of seagrass Thalassia hemprichii (Fig. 1) were collected from the sand substrate at a depth of 3-4 $\mathrm{m}$ near the beach of Barrang Lompo Island, Makassar (Fig. 2). The seagrass was washed with distilled water to remove salt and any attached material, then placed at room temperature until dry. The dried grass was ground to obtain a fine particle size for easy extraction. Biofilm bacteria were obtained using the dredging method near the pole dock at Potere Wharf, Makassar (Fig. 3) and taken at a depth of $1 \mathrm{~m}$ from the surface sea. Samples of biofilm-forming bacterial were placed in sample bottles.

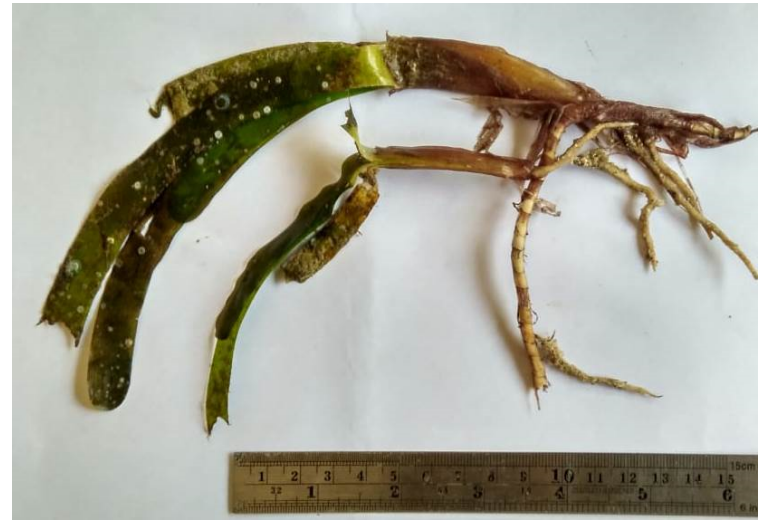

Fig. 1 The samples of seagrass T. hemprichii were collected from the beach of Barrang Lompo Island, Makassar, South Sulawesi, Indonesia.

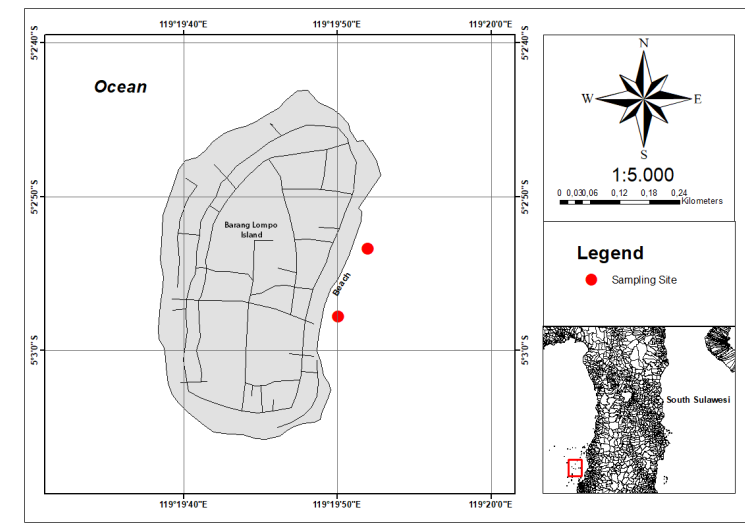

Fig. 2 Map and the sampling points of seagrass T. hemprichii on the beach of Barrang Lompo Island, Makassar, South Sulawesi, Indonesia.

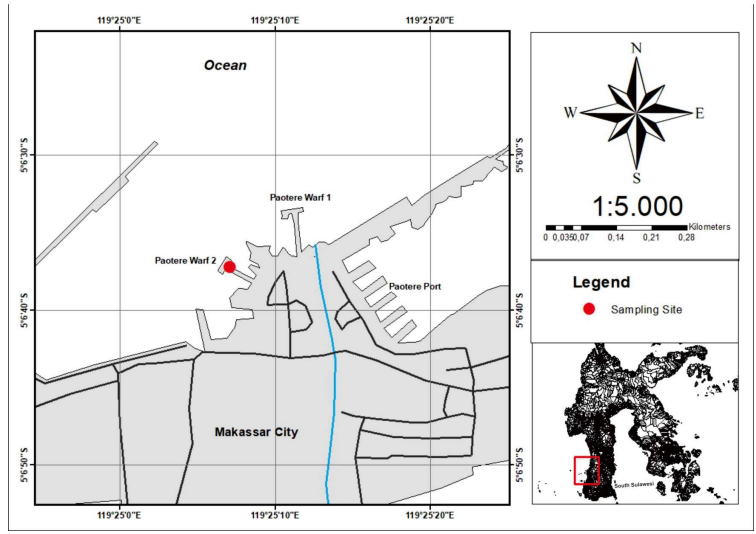

Fig. 3 Map and the sampling points of biofilm at Potere Wharf, Makassar, South Sulawesi, Indonesia. 


\section{Isolation of biofilm bacteria}

The samples of biofilm-forming bacteria were serially diluted to $10^{-1}-10^{-4}$ with a physiological solution of $\mathrm{NaCl} 0.9 \%$. Diluted bacteria were then inoculated onto Medium Marine Agar media (ATCC) in a Petri dish and incubated at $37^{\circ} \mathrm{C}$ for $24 \mathrm{~h}$. The number of colonies formed as well as characteristics of each colony was investigated including colony colour, shape, elevation, texture, and Gram staining. Distinct colonies were isolated from the Agar Nutrient and grown in test tubes. The composition of Nutrient Agar media (MERCK) was as follows: $15 \mathrm{~g}$ agar, $3 \mathrm{~g}$ beef extract, $5 \mathrm{~g}$ peptone, $5 \mathrm{~g} \mathrm{NaCl}, 2 \mathrm{~g}$ yeast extract/per $1000 \mathrm{ml}$ distilled water.

\section{Biochemical analysis of bacterial isolates}

Fermentation tests of isolates for utilization of glucose, lactose, mannitol, maltose, and saccharose substrates, as well as other support tests, were performed. The ability to utilize citrate and nitrate was also examined. Other tests include motility, indole, catalase, and urease activity. $100 \mu \mathrm{l}$ of suspended bacteria were injected into appropriate test strips and incubated at $35-37^{\circ} \mathrm{C}$ for $48 \mathrm{~h}$. Any change in the colour was measured according to instructions provided $^{19,20}$.

\section{T. hemprichii extraction}

Extraction of T. hemprichii was conducted using the maceration method ${ }^{21,22}$. Methanol (1:3 w/v) was used as the extraction solvent for dried T. hemprichii. Samples were placed in a water bath at $60^{\circ} \mathrm{C}$ for $24 \mathrm{~h}$, then filtered using fast qualitative filter paper Whatman No. 1 . The residue was re-extracted three times following the same procedure. The filtrate was stored in at $10^{\circ} \mathrm{C}$. All the filtrates were combined, then concentrated with the rotary evaporator. The formula to calculate the extract yield is

$$
\operatorname{EYV}(\%)=\frac{B_{2}}{B_{1}} \times 100,
$$

where EYV is the extract yield value (\%), $B_{1}$ is the initial sample weight, and $B_{2}$ is the final weight (extract value).

\section{Extract and control solutions}

The positive control solution contained $0.9 \mu \mathrm{g} / 1$ chloramphenicol dissolved into $6 \mathrm{ml}$ methanol then homogenized using vortex. The negative control solution was the methanol solvent used in extract preparation. The $T$. hemprichii extract was prepared by dissolving $0.01 \mathrm{mg} / 1$ extract with $2 \mathrm{ml}$ methanol
Table 1 The macroscopic morphology of biofilm bacterial colonies.

\begin{tabular}{lcccc}
\hline \multirow{2}{*}{$\begin{array}{l}\text { Type of } \\
\text { Biofilm }\end{array}$} & \multicolumn{4}{c}{ Characteristics of colony } \\
\cline { 2 - 5 } & Colour & Shape & Morphology & Elevation \\
\hline P1 & green & irregular & undulate & convex \\
P2 & brown & irregular & undulate & raised \\
P3 & white & circle & filamentous & raised \\
P4 & green & irregular & undulate & flat \\
P5 & yellow & irregular & filamentous & flat \\
P6 & brown & circle & undulate & convex \\
P7 & yellow & irregular & filamentous & umbonate \\
P8 & yellow & circle & filamentous & raised \\
P9 & yellow & irregular & undulate & raised \\
\hline
\end{tabular}

then homogenized using a vortex mixer. The positive control solution was used as a comparison to establish whether the extract exhibited antibacterial potential. If the diameter of the zone of inhibition exceeds that of the positive control then the T. hemprichii extract would be considered to have potential as an antimicrofouling agent.

\section{Biofilm bacterial inhibition assay}

Suspensions of biofilm bacteria cultures $(0.3 \mathrm{ml})$ were used to inoculate $50 \mathrm{ml}$ nutrient agar solution in $300 \mathrm{ml}$ Erlenmeyer flasks. Samples were shaken to make homogeneous and poured into a Petri dish and allowed to solidify. $6 \mathrm{~mm}$ filter paper discs were soaked with $T$. hemprichii extract solution then placed on the biofilm bacteria culture plate. Plates were incubated at $37^{\circ} \mathrm{C}$ for $48 \mathrm{~h}$ and the zone of bacterial growth inhibition around the paper disc was measured. Antifouling activity was determined based on the presence of an inhibitory zone around the paper disc. Chloramphenicol solution, positive control, and methanol solvent, negative control, were used to compare the activity of $T$. hemprichii extract against of biofilm-forming bacteria. In subsequent experiments, T. hemprichii extract was also tested for activity against each type of bacterial isolate obtained from biofilm bacterial using the same procedure.

\section{RESULTS AND DISCUSSION}

\section{Measurement and characteristic of biofilm bacterial colonies}

Biofilm-forming bacteria were sampled from wood pole scour at the wharf at Potere, the total bacteria obtained was $6.0 \times 10^{6} \mathrm{CFU} / \mathrm{g}$. Examination of colonies formed on Marine Agar media allowed identification of nine types of bacterial colonies, 
based on the macroscopic morphological characteristics. Morphologically, the isolates showed variations in the colour, margin, shape, and texture of the colonies (Table 1). The colonies obtained exhibited five colours, namely, yellow, brownish white, yellowish white, milky white and brownish. In addition, there were two forms of colonies, round and irregular; with the colony margins being entire, undulate and filamentous; elevations were flat, convex, and raised.

Macroscopic characteristics, such as colony morphology, are often helpful in microorganism identification. A colony is a mass of microorganisms all originating from a single mother cell. Hence within a colony microorganism are all genetically uniform and each colony represents an individual bacterial clone ${ }^{25}$. Each type of bacteria will display different colony morphologies ${ }^{22,23}$. Colonies may be coloured due to the properties of the growth media or pigment production by the bacteria. In certain differential and indicator mediums, bacteria may produce coloured colonies due to changes in $\mathrm{pH}$ or enzymatic activity ${ }^{24}$. Pigments produced by bacteria may also colour the colonies. The distinct morphological characteristics observed from individual colonies were predictive of different biochemical responses among the isolates. However, microscopic examination provided less information as nine of the bacteria isolates exhibited sphereshaped cells: P1, P2, P5, P6, P7, and P8, while other isolates were Gram-negative and rod-shaped: P3, $\mathrm{P} 4$, and $\mathrm{P} 9$.

The biochemical tests for each isolate included analysis of fermentation ability on sugar substrates, ability to utilize citrate and nitrate, urease activity, $\mathrm{H}_{2} \mathrm{~S}$ formation, motility, and indole formation. Isolates P5 and P7 displayed similar biochemical and morphological characteristics and it is suspected that these two isolates are the same type. While the other isolates exhibit many biochemical differences, although the morphological examination of the colonies and Gram staining are the same. In total, the number of isolates obtained is eight distinct types. These eight isolates demonstrated phenotypic diversity, and none of the eight isolates shared phenotypic patterns (Table 2).

Examination of colony morphology is a method often used to describe the characteristics of bacteria growing on agar media; however, there are limits to its use in identification. It is difficult to utilize morphology as the basis for classification of bacteria because many species form fractal colonies due to environmental, physicochemical, and biological factors. In contrast, the morphology of a bacterial colony on a solid agar medium depends on the nutrient diffusion field which is two-dimensional. When concentrations of nutrients are low, diffusion growth of bacteria will be limited ${ }^{26}$.

Distinct bacterial isolates will often produce different metabolites due to altered activity of metabolic enzymes. These characteristics can be detected based on the substrate in growth media as well as through the use of a colour indicator after adding the test reagent ${ }^{24}$. When the agar changes colour, it is usually due to bacteria either feeding on the nutrients that produce the colour or from changes in the $\mathrm{pH}$ of the external environment through the release of acidic or basic by products $^{19,20}$.

\section{T. hemprichii extraction}

The value of yield was determined by the dry weight of Thalassia hemprichii of $275 \mathrm{~g}$ and the extract obtained, $83.4 \mathrm{~g}$. The amount of extract produced using methanol was calculated with the formula (1) to have the EYV 30\%, indicating a high quantity based on the weight of the extracted compared to the initial sample weight. The reason for using methanol as the solvent for $T$. hemprichii extraction was due to it being a polar solvent with hydrogen bond potential. This type of solvent should allow the bioactive compounds contained in T. hemprichii to dissolve easily. As a result, the bioactive compounds could be easily obtained, as judged by the high yield ${ }^{27}$. The solubility of a substance in a polar solvent depends on the compounds ability to form hydrogen bonds ${ }^{28}$. The amount of $T$. hemprichii extract obtained with methanol was higher than when n-hexane was used as a solvent. This suggests that T. hemprichii contains more bioactive compounds that are polar compared to those that are nonpo$\operatorname{lar}^{14}$.

\section{Antimicrofouling potential of T. hemprichii}

Analysis of the antimicrofouling ability of T. hemprichii extract on biofilm-forming bacteria culture as a whole was conducted using the agar diffusion method. There was an inhibition zone formed around the paper disc on nutrient agar media containing T. hemprichii extract. The disc with T. hemprichii extract produced a $26 \mathrm{~mm}$ inhibitory zone and chloramphenicol, the positive control, caused a $28 \mathrm{~mm}$ inhibitory zone to be formed. No growth inhibition was observed with the paper disc containing methanol as a negative control (Fig. 4). The inhibitory ability of 
Table 2 The biochemical characteristics of the biofilm bacterial isolates.

\begin{tabular}{lccccccccc}
\hline Isolate & P1 & P2 & P3 & P4 & P5 & P6 & P7 & P8 & P9 \\
\hline Microscopic Gram staining & + & + & - & - & + & + & + & + & - \\
Microscopic shape & $\mathrm{S}$ & $\mathrm{S}$ & $\mathrm{R}$ & $\mathrm{R}$ & $\mathrm{S}$ & $\mathrm{S}$ & $\mathrm{S}$ & $\mathrm{S}$ & $\mathrm{R}$ \\
Glucose fermentation & - & + & + & + & + & + & + & + & + \\
Sucrose fermentation & + & - & + & + & + & + & + & + & + \\
Fructose fermentation & - & + & + & + & + & - & + & - & - \\
Lactose fermentation & - & + & + & + & - & - & - & - & + \\
Monnitol fermentation & + & + & - & - & - & & - & - & - \\
Inositol fermentation & - & - & - & & - & + & - & & + \\
Starch hydrolysis & - & + & + & - & + & + & + & & - \\
Catalase & + & - & - & + & - & + & - & & + \\
Citrate (utilization) & + & + & + & - & + & - & + & & + \\
Urease (utilization) & + & + & + & - & + & + & + & & + \\
Nitrate reduction) & + & + & + & + & + & + & + & & + \\
H S formation & - & - & - & - & - & + & - & & - \\
Motility & + & + & - & + & - & + & - & & - \\
Indole & + & - & - & + & - & + & - & & + \\
\hline
\end{tabular}

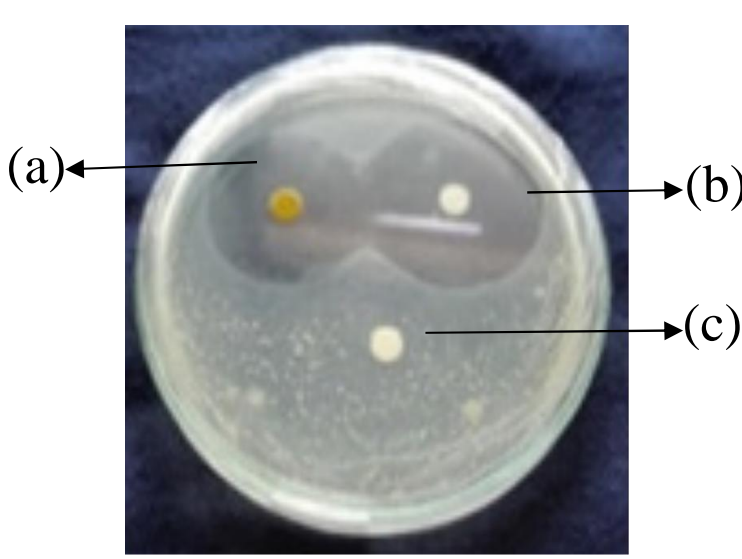

Fig. 4 Test of T. hemprichii extract activity as an antimicrofouling agent; (a) inhibitory zone in the T. hemprichii extract, (b) inhibitory zone in the positive control, and (c) no inhibitory zone in the negative control.

T. hemprichii was similar to the positive control, indicating that the extract has potential as an antifouling agent.

T. hemprichii extract contains reducing sugars as well as bioactive compounds including flavonoids, alkaloids, and steroids, which are toxic to microorganism $^{14,29}$. In addition, the bioactive flavonoid (flavones glycoside liteolin 7-O- $\beta$-D-glucopyransyl2-sulphate) isolated from T. testudinum was able to inhibit the growth of fouling organisms and fungi ${ }^{22}$. Alkaloids are a class of toxic compounds that destroy the peptidoglycan component of bacteria resulting in the irregular arrangement of the cell wall ${ }^{30,31}$. Steroids and related compounds cause toxicity to
Table 3 The formation of inhibition zone of the biofilm bacterial isolates.

\begin{tabular}{lccc}
\hline Isolate & \multicolumn{3}{c}{ Inhibition zone of bacterial growth (mm) } \\
\cline { 2 - 4 } $\begin{array}{l}\text { biofilm } \\
\text { bacteria }\end{array}$ & $\begin{array}{c}\text { T. testudinum } \\
\text { extract }\end{array}$ & $\begin{array}{c}\text { Chloramphenicol } \\
\text { (+ control) }\end{array}$ & $\begin{array}{c}\text { Methanol } \\
(- \text { control) }\end{array}$ \\
\hline P1 & 26 & 28 & 0 \\
P2 & 21 & 28 & 0 \\
P3 & 27 & 28 & 0 \\
P4 & 24 & 28 & 0 \\
P5 & 14 & 28 & 0 \\
P6 & 9 & 28 & 0 \\
P7 & 17 & 28 & 0 \\
P8 & 26 & 28 & 0 \\
P9 & 26 & 28 & 0 \\
\hline
\end{tabular}

microorganisms through increased the permeability of the cell membrane, resulting in leakage of cellular contents ${ }^{17}$. T. testudinum extract also contains phenol compound that can damage the cell membrane, causing changes in cell permeability leading to inhibition of cell growth or cell death ${ }^{22}$. In addition, phenol compounds can alter the conformation of membrane proteins, distorting the cell wall, and promote lysis ${ }^{32,33}$.

T. hemprichii extract was tested on each of 8 bacterial isolates to determine if growth inhibition occurred with each of biofilm-forming bacteria. This analysis utilized the formation of a clear zone as an indicator of growth inhibition (Table 3). The T. hemprichii extract has different inhibitory ability against bacteria from each group. Isolates that were sensitive to $T$. hemprichii extract include $\mathrm{P} 1,26 \mathrm{~mm}$; 
P3, $27 \mathrm{~mm}$; P4, $24 \mathrm{~mm}$; P8, $27 \mathrm{~mm}$; and P9, $26 \mathrm{~mm}$ with the size of inhibition zone indicated. The inhibition zone produced by T. hemprichii extract for these isolates were similar to the chloramphenicol, the positive control, of $28 \mathrm{~mm}$. The other bacterial isolates displayed a significant difference in the inhibitory zones due to T. hemprichii extract. In these more resistant isolates the inhibitory zone diameter was as follows. P2, $21 \mathrm{~mm}$; P5, $14 \mathrm{~mm}$; P6, $9 \mathrm{~mm}$; and $\mathrm{P} 7,17 \mathrm{~mm}$. The results for isolates $\mathrm{P} 5$ and P7 are not substantially different, and these bacteria exhibit similar morphological characteristics and may belong to the same genus. The differences in the inhibitory zone produced by T. hemprichii extract may be related to the adaptive ability and to the nature of microbial resistance of each bacteria $^{34}$. It is possible that the composition of the more complex and simpler components of Gramnegative bacterial cell wall may affect the toxicity of compounds in the T. hemprichii extract ${ }^{35,36}$. Gramnegative bacteria are generally more sensitive to polar compounds, compared to Gram-positive cells, as they lack the peptidolglycan cell wall. The outer membrane of Gram-negative bacteria is composed of lipopolysaccharides, porins, and lipoproteins. These components may facilitate the passive diffusion of low molecular, weight hydrophilic compounds, such as alkaloids and flavonoids, present in T. hemprichii ${ }^{37,38}$.

The morphology of leaves of T. hemprichii is thick, wide, and long. The shape of the leaves may enhance their ability to store more bioactive compounds. This morphology of T. hemprichii may also provide a substrate for epiphytic organisms consisting of flora (macro and microalgae), fauna, bacteria, and detritus and any other sessile organism ${ }^{38,39}$. In addition, conditions of pressure that occur naturally as well as competition of T. hemprichii with other organisms may promote the production and accumulation of several types of bioactive secondary metabolites for use as a defence against predators, parasites, and attacks from other organisms ${ }^{38}$.

\section{CONCLUSIONS}

The results presented here indicate that the crude methanol extract of T. hemprichii exhibits good antimicrofouling activity against several biofilmforming bacteria. The inhibitory zone diameter of the extract is $26 \mathrm{~mm}$, similar to the inhibitory zone of $28 \mathrm{~mm}$ for chloramphenicol, the positive control. Although not all of the biofilm-forming bacteria were equally sensitive, overall the bioactive material present in T. hemprichii extract exhibits good antimicrofouling activity.

Acknowledgements: The authors would like to thank the Director of the Research Centre of Hasanuddin University, Makassar, Indonesia on the implementation of this study and thank the Dean of Faculty of Mathematics and Natural Sciences, Hasanuddin University, Makassar, Indonesia.

\section{REFERENCES}

1. Almeida E, Diamantino TC, De Sousa O (2007) Marine paints: the particular case of antifouling paints. Prog Org Coat 59, 2-20.

2. Alla S, Alexandra B, Florence V, Véronique L, Philippe D, Jean-Luc M, Nathalie B (2009) Antifouling activity of macroalgal extracts on Fragilaria pinnata (Bacillariophyceae): A comparison with Diuron. Aquat Toxicol 94, 245-54.

3. Turner A, Glegg G (2014) TBT-based antifouling paints remain on sale. Mar Pollut Bull 88, 398-400.

4. Bellas J (2006) Comparative toxicity of alternative antifouling biocides on embryos and larvae of marine invertebrates. Sci Total Enviro 367, 573-85.

5. Gueuné H, Thouand G, Durand MJ (2009) A new bioassay for the inspection and identification of TBTcontaining antifouling paint. Mar Pollut Bull 58, 1734-8.

6. International Maritime Organization (2002) Antifouling Systems, IMO, London.

7. Evans SM, Birchenough AC, Branchato MS (2000) The TBT ban: out of the frying pan into the fire? Mar Pollut Bull 40, 204-11.

8. Marechal J, Hellio C (2009) Challenges for the development of new non-toxic antifouling solutions. Int $J$ Mol Sci 10, 4623-37.

9. Raveendran TV, Limna Mol VP (2009) Natural product antifoulants. Curr Sci 97, 508-20.

10. Waycott M, McMahoon K, Mellors J, Calladine A, Kleine D (2004) A Guide Tropical Seagrasses of The Indo-West Pacific, James Cook University, Townsville.

11. Kuo J (2007) New Monoecious seagrass of Hallophila sulawesii (Hidrocharitaceae) from Indonesia. Aqauat Bot 87, 171-5.

12. Mujizat K, Aditya HN, Juraij, Ilham AT (2016) Seagrass biodiversity at three marine ecoregions of Indonesia: Sunda Shelf, Sulawesi Sea, and Banda Sea. Biodiversitas 17, 585-91.

13. Christian M, Peter DRM, Eric BT, Justin JR, Robert WH, John C (2009) Evaluation of dihydrouridine as an antifouling additive in marine paint. Int Biodeter Biodegr 63, 529-32.

14. Hellio C, De La Broise D, Dufossé L, Le Gal Y, Bourgougnon $N$ (2001) Inhibition of marine bacteria by extracts of macroalgae: potential use for environmentally friendly antifouling paints. Mar Environ Res 52, 231-47. 
15. Bhadury P, Wright PC (2004) Exploitation of marine algae: biogenic compounds for potential antifouling applications. Planta 219, 561-78.

16. Tupan CI, Uneputty PA (2017) The growth and population dynamics of seagrass Thalassia hemprichii in Suli Waters, Ambon Island. OP Conf Ser: Earth Environ Sci, 89012008.

17. Ravikumar S, Thajuddin N, Suganthi P, Inbaneson SJ, Vinodkumar T (2008) Bioactive potential Of seagrass bacteria against human bacterial pathogens. $J$ Environ Biol 31, 387-9.

18. Bindhu J, Sivapriya V, Silambarasan G, Yasodha P, Girija R (2017) Antidiabetic activity of Thalassia Hemprichii (Seagrass) in alloxan induced diabetic mice. IOSR J Pharm Biol Sci 12, 24-33.

19. Prescott LM, Harley GP, Klein DE (1993) Microbiol, W. Brown Publishers, Iowa, USA.

20. MacFaddin, Jean F (1980) Biochemical Tests for Identification of Medical Bacteria, Williams \& Wilkins, Baltimore, pp 173-83.

21. El-Hady HA, Daboor SM, Ghoniemy AE (2007) Nutritive and antimicrobial profiles of some seagrasses from Bardawil Lake, Egypt. Egypt J Aquat Res 3, 103-10.

22. Jensen PR, Jenlins KM, Porter D, Fenical W (1998) Evidence that a new antibiotic flavone glycoside chemically defends the seagrass Thalassia testudinum against zoosporic fungi. Appl Environ Microbiol 64, 1490-6.

23. Fahruddin, Asadi A (2015) Use of organic materials wetland for improving the capacity of sulfate reduction bacteria (SRB) in reducing sulfate in acid mine water (AMW). Asian J Microbiol Biotech Env Sci 17, 321-4.

24. Mohammad BT, Hala IA, Atef J, Saleh AL, Christian $\mathrm{K}$ (2017) Isolation and characterization of thermophilic bacteria from Jordanian Hot Springs: Bacillus licheniformis and Thermomonas hydrothermalis isolate as potential producers of thermostable enzymes. Int J Microbiol 2017, 1-12.

25. Virginia V, Henk JB, Willem N, Joop de Vries, Henny C (2003) Relations between microscopic and macroscopic physicochemical properties of bacterial cell surfaces: An AFM study on Streptococcus mitis Strains. Langmuir 19, 2372-7.

26. Matsuyama T, Mitsugu M (1993) Fractal morphogenesis by a bacterial cell population. Crit Rev Microbiol 19, 117-35.

27. Jebasingh SEJ, Lakshmikandan M, Sivaraman K, Uthiralingam M (2016) Assessment of antibacte- rial, antifungal property and purification of bioactive compounds from Seagrass, Thalassia hemprichii. In: Proceedings of the National Academy of Sciences, India Section B: Biological Sciences 86, pp 905-10.

28. Iyapparaj P, Revathi P, Ramasubburayan R, Prakash S, Anantharaman P, Immanuel G, Palavesam A (2013) Antifouling activity of the methanolic extract of Syringodium isoetifolium and its toxicity relative to tributyltin on the ovarian development of brown mussel Perna indica. Ecotoxicol Environ Saf 89, 231-8.

29. Nugraheni SA, Khoeri MM, Kusmita L, Widyastuti Y, Radjasa OK (2010) Characterization of carotenoid pigments from bacterial symbionts of seagrass Thalassia hemprichii. J Coast Dev 14, 51-60.

30. Marsh PD (1995) Dental plaque. In: Lappin-Scott HM, Costerton JW (eds) Microbial Biofilms, Cambridge University Press, Cambridge, pp 282-300.

31. Arampatzi SI, Giannoglou G, Diza E (2011) Biofilm formation: A complicated microbiological process. Aristotle Univ Med J 38, 21-9.

32. Velioglu YS, Mazza G, Gao L, Oomah BD (1998) Antioxidant activity and total phenolics in selected fruits, vegetables, and grain products. J Agric Food Chem 46, 4113-7.

33. Ragupathi RKR, Arumugam R, Grignon-Dubois $M$, Anantharaman P (2012) Antioxidant activity of seagrasses of the Mandapam coast, India. Pharm Biol 50, 182-7.

34. Rosenberg M, Bayer EA, Delarea J, Rosenberg E (1982) Role of thin fimbriae in adherence and growth of Acinetobacter calcoaceticus RAG-1 on hexadecane. Appl Environ Microbiol 44, 929-37.

35. Egan S, Holmström C, Kjelleberg S (2001) Pseudoalteromonas ulvae sp. nov., a bacterium with antifouling activities isolated from the surface of a marine alga. Int J Syst Evol Microbiol 51, 1499-504.

36. Watnick P, Roberto K (2000) Biofilm, city of microbes. $J$ Bacteriol 182, 2675-9.

37. Branen, LA, Davidson PM (1993) Antimicrobials in Foods, Marcel Dekker, New York.

38. Michael TS, Shin HW, Hanna R, Spafford DC (2008) A review of epiphyte community development: Surface interactions and settlement on seagrass. $J$ Environ Biol 29, 629-38.

39. Harlin MM, Villalard-Bohnsack M (2001) Seasonal dynamics and recruitment strategies of the invasive seaweed Grateloupia doryphora (Halymeniaceae, Rhodophyta) in Narragansett Bay and Rhode Island Sound, Rhode Island, USA. Phycologia 40, 468-74. 